\title{
Stem Cell Populations and Regenerative Potential in Chronic Inflammatory Lung Diseases
}

\author{
Fabio Bucchieri, Alberto Fucarino, Luigi Rizzuto, Alessandro Pitruzzella, Antonio Noto, \\ Francesco Cappello* and Giovanni Zummo
}

Department of Experimental Medicine, Human Anatomy Section, University of Palermo, Italy

\begin{abstract}
Several acute and chronic inflammatory pathologies of the lung are accompanied by structural modifications of airway mucosa that vary depending on the severity, duration and type of the disease. These morphological changes, that determine organ dysfunction, are not always reversible. Indeed, the cycle of injury and repair, influencing airway wall regeneration, may sometimes break off and an exacerbation of the pathology may occur. The mechanisms at the base of airway remodelling during inflammation have been widely studied and numerous evidences indicate that the molecular dialogue among the cells of the mucosa has an essential role in orchestrating cell differentiation and tissue repair. In this review, we revise old notions on pulmonary morphology at the light of some of the most recent discoveries concerning stem cell differentiation, tissue homeostasis and organ regeneration of the lung.
\end{abstract}

Key Words: Stem cells, airways, epithelial mesenchymal trophic unit, histogenesis.

\section{MICROSCOPIC ANATOMY OF THE LUNG}

The human lung is a parenchymal organ that derives from the branching of a hollow structure, the main bronchus. From a strictly anatomical point of view, the morphofunctional units of the lung are pulmonary lobules. These lobules are bound by septa of connective tissue (interlobular septa) which are in continuity with the sub-mesothelial connective layer of the visceral pleura, and are macroscopically visible on the external surface of the organ, as well as on the inner surface of the parenchyma [1].

Pulmonary lobules derive from the smallest parts of conducting airways, called bronchioles, characterised by the absence of cartilage in their walls and a diameter smaller than $1 \mathrm{~mm}$. Pulmonary lobules have a diameter of $2 \mathrm{~cm}$ and are constituted by: (a) one terminal bronchiole, from which derive (b) 3-6 respiratory bronchioles, each one supplying (c) 3-5 alveolar sacs [2]. The air moves from the respiratory bronchioles through alveolar ducts to alveolar sacs (Fig. 1). The part connecting the alveolar ducts to the alveolar sacs has been described as "atrium".

Each respiratory bronchiole with its alveolar sacs is described as an acinus, the functional subunit of the pulmonary lobules. Indeed, the terminal bronchioles are not involved in hematosis, because of their lack of alveoli that, vice versa, delimit the respiratory bronchioles, alveolar ducts and alveolar sacs.

Terminal bronchioles, respiratory bronchioles, alveolar ducts and alveolar sacs develop around the 16th to 28th week of gestation from the expansion and branching of major airways [3]. As a consequence, their structure resembles that of

*Address correspondence to this author at the Via alla Falconara 120-90136 Palermo, Italy; E-mail: francapp@ hotmail.com the other parts of the lower airways: they have a wall comprised of three layers: (a) an internal mucosa; (b) an intermediate submucosa; and (c) an external adventitia [4].

The mucosa of the bronchioles is made up by a cuboidal/columnar epithelium laying on a lamina propria (Fig. 1). The epithelium is composed of several different cytotypes, whose structural and functional features are described in Table 1. Between the epithelium and the lamina propria there is a thin basal membrane, formed by a lamina basalis and a lamina reticularis; these two laminae have a different proteins composition, the basalis being synthesised from epithelial elements and the reticularis from the connective ones [1].

The lamina propria is composed of loose connective tissue, and it contains smooth muscle cells, myofibroblasts, fibrocytes, macrophages, lymphoid cells, mast cells, endothelial cells of hematic and lymphatic capillaries and nerve fibres; a pool of spindle cells are indicated as fibroblasts, but a part of them are probably a heterogeneous population of otherwise non-specifiable cells [4]. Smooth muscle cells are intimately associated with numerous elastic fibers that, together with a small amount of reticular and collagenous fibres, form the feltwork of lamina propria.

The structure of the alveoli greatly differs from that of the bronchioles. They are delimited by fibroelastic septa (interalveolar septa), that derive from the interlobular septa; nevertheless, they communicate among themselves via pores of Kohn (Fig. 1). The alveoli are bordered by both squamous (Type I pneumocytes, TIPs) and cuboidal (Type II pneumocytes, TIIPs) epithelial cells [5]. The former are large and flat cells, functionally involved in gas exchange, that cover more than $90 \%$ of the alveolar surface; they contribute to form the so-called "air/blood barrier" together with capillary endothelial cells and each own LB [6]. 
Table 1. This Table Resumes the Main Morphofunctional Features of the Bronchiolar Epithelial Cell Types Together with Some of their Pathophysiologic Roles

\begin{tabular}{|c|c|c|c|c|}
\hline Cytotype & Ultrastructural Features & Functions & Other Putative Roles & Comments \\
\hline Ciliated cells & $\begin{array}{l}\text { Cuboidal, each cell has } \\
\text { approximately } 250 \text { cilia; each } \\
\text { cilium is approximately } 6 \text { um long }\end{array}$ & $\begin{array}{l}\text { Transport of } \\
\text { mucus stream }\end{array}$ & Unknown & $\begin{array}{c}\text { The most prevalent cytotype; } \\
\text { they decrease during chronic } \\
\text { inflammation }\end{array}$ \\
\hline Clara' cells & $\begin{array}{l}\text { Cuboidal/columnar non ciliated, } \\
\text { non-mucus secreting cells. Granules } \\
\text { are present in apical cytoplasm }\end{array}$ & $\begin{array}{l}\text { Secretory function } \\
\text { contributing to the cleaning } \\
\text { of smallest airways }\end{array}$ & $\begin{array}{l}\text { Progenitors of other cells } \\
\text { (Type II Pneumocytes ?); } \\
\text { role in surfactant production }\end{array}$ & $\begin{array}{l}\text { The second most prevalent } \\
\text { cytotype; they augment during } \\
\text { chronic inflammation }\end{array}$ \\
\hline Basal cells & $\begin{array}{l}\text { Small round cells with scarce } \\
\text { cytoplasm, close to the } \\
\text { basal membrane }\end{array}$ & $\begin{array}{l}\text { Precursors of other } \\
\text { cytotypes }\end{array}$ & Stem cells & $\begin{array}{l}\text { They are rare in bronchioles; } \\
\text { we do not know yet which } \\
\text { cytotypes they originate; they are } \\
\text { also involved in carcinogenesis }\end{array}$ \\
\hline $\begin{array}{l}\text { Neuroendocrine } \\
\text { (Kulchitsky) } \\
\text { cells }\end{array}$ & $\begin{array}{c}\text { Small round cells with } \\
\text { numerous secretory granules }\end{array}$ & $\begin{array}{c}\text { Part of diffuse } \\
\text { neuroendocrine system }\end{array}$ & Unknown & $\begin{array}{l}\text { They are rare in bronchioles; } \\
\text { they may be present single } \\
\text { or in small groups; } \\
\text { they may originate microcytoma }\end{array}$ \\
\hline Goblet cells & $\begin{array}{l}\text { Cuboidal/columnar mucus } \\
\text { secreting cells }\end{array}$ & $\begin{array}{l}\text { Secretory function } \\
\text { contributing to the cleaning } \\
\text { of smallest airways }\end{array}$ & Unknown & $\begin{array}{l}\text { They are rare in bronchioles; } \\
\text { they augment during } \\
\text { chronic inflammation }\end{array}$ \\
\hline Lymphocytes & $\begin{array}{l}\text { Small round cells with scarce } \\
\text { cytoplasm, scattered among the } \\
\text { other cytotypes or adjacent to the } \\
\text { luminal surface of epithelium }\end{array}$ & Immune surveillance & Unknown & $\begin{array}{l}\text { They are rare in bronchioles; } \\
\text { they augment during } \\
\text { chronic inflammation }\end{array}$ \\
\hline
\end{tabular}

The TIIPs are cuboidal elements, containing small microvilli, which from the $35^{\text {th }}$ week of gestation onwards produce and secrete surfactant, a lipoprotein that reduces the surface tension of fluids within the alveoli. TIPs are considered incapable of division, while TIIPs may proliferate after injury [7]. Moreover, TIIPs are often thought to share functional similarities with the Clara' cells, although their secretory granules are different.

Finally, the alveoli also contain immune system cells (i.e. migrating lymphocytes and monocytes, and resident macrophages) as well as other uncharacterised "mesenchymal" elements scattered into the fibroelastic stroma (Fig. 1) [8].

\section{THE EPITHELIAL-MESENCHYMAL TROPHIC UNIT}

Having been considered two distinct morphofunctional layers for a long time, the epithelium and the lamina propria of bronchi and bronchioles are now referred to as the epithelial-mesenchymal trophic unit (EMTU) [9].

From a strictly functional point of view, the mucosa of the bronchial tree is a physical barrier that separates the external environment from the internal milieu of the lungs [10]. Like the bronchial epithelium does via mucous-ciliary interaction, the bronchiolar epithelium also acts by removing inhaled particulate materials via serous production by Clara' cells and does the ciliary clearance. Epithelial damage (disepithelisation), i.e. during asthma, may compromise this function [11].

Under normal conditions, the epithelium of the airway that has lost cuboidal/columnar cells may repair itself with remarkable speed. Indeed, the basal cells, which are more firmly attached to the underlying basal membrane, via hemidesmosomes, progressively restore the normal epithelium by a process of cell proliferation and differentiation [12]. Although it is commonly believed that frequent episodes of disepithelisation and re-epithelisation, i.e. following chronic infective/inflammatory diseases, are the basis of carcinogenesis in some anatomical regions (like uterine exocervix, stomach, liver, etc), since they increase the possibility of DNA mutations, we want to state that bronchial carcinogenesis is an extremely rare complication of asthma. This fact may indicate that 1 ) other events besides basal cell mutation are necessary for cancer development in airway epithelium and/or that 2) the DNA repair mechanisms are more efficient in airway epithelium. In addition, we do not have sufficient knowledge on EMTU biology, specifically regarding stem cell (SC) niches. For example, basal cells of the epithelium are commonly considered as a population of SCs, but the underlying connective tissue lacks the well recognised stem phenotype.

It is widely recognised that the epithelium and the mesenchyme cooperate in foetal lung development through exchange of soluble mediators; this cooperation plays a pivotal role in airway growth and branching. [13]. Furthermore, it is well known that epithelial elements and subepithelial mesenchymal cells also interact in adult tissue via autacoid mediators, cytokines and growth factors [13]. The existence of cell-cell contacts through gap junctions between subepithelial fibroblasts, as well as the presence of communication channels between epithelial cells and myofibroblasts has also 


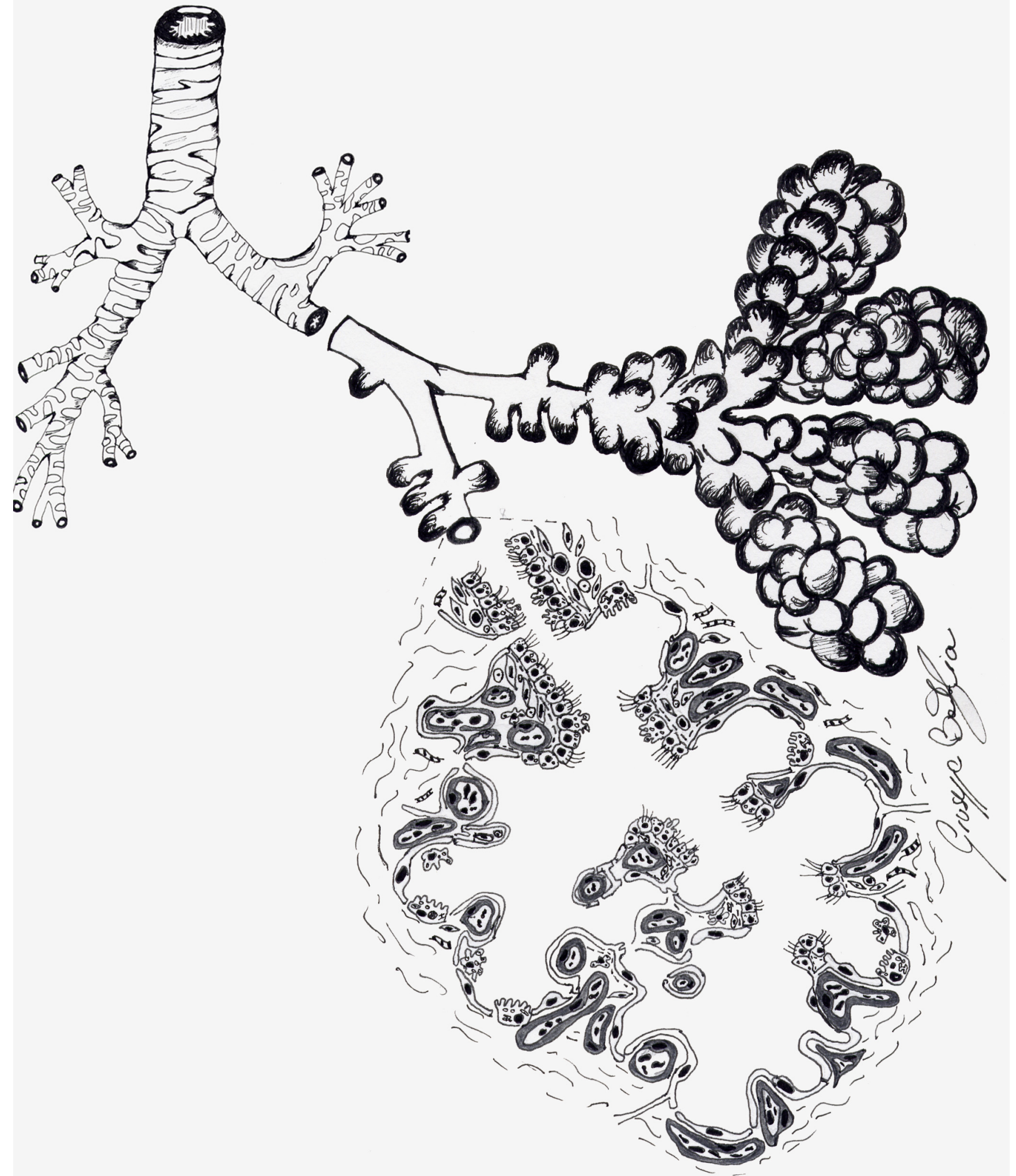

Fig. (1). This draft reproduces the bronchial tree (upper left) and lobules with a schematic view of an acinus (lower right). Arrows indicate Kohn's pores. See the text for more details.

been shown [12]. We hypothesise that a migration of undifferentiated (stem?) elements between the epithelium and LP may occur (Fig. 2). In our opinion, epithelial and subepithelial (mesenchymal) cells share a common progenitor in many adult mucosae, such as the airway mucosa. These progenitors may be responsible for the homeostasis and remodelling of the EMTU during acute/chronic inflammations and their genetic alterations may determine cancer development. 


\section{HOW MANY STEM CELLS EXIST IN THE LUNG?}

Studies on the regenerative potential of tissues date as far back as one century. The first researcher that described the possibility to preserve the viability of an isolated tissue and also to induce its further growth was Professor Ross Granville Harrison (1870-1959), an anatomist of the Yale University of New York, in 1907 [14]. He became aware that occasionally isolated elements in culture have the capacity to re-establish the tissue from which they originate. Basically, without knowing it, he was already studying SCs.

Today, it is believed that the mechanisms responsible for tissue regeneration and organ homeostasis in adult organisms are two: 1) mitosis of differentiated functioning cells, with a preserved proliferative activity (for example, hepatocytes after a partial hepatectomy) and 2) generation of newly differentiated cells, derived from SCs (for example, haematopoiesis from bone marrow precursors).

SCs are undifferentiated elements able to self-renew and differentiate into specialised cells. They are probably more resistant to toxic noxae and other damaging agents than differentiated cells, and they are also able to restore and renew almost all tissues of the human body [15]. They have been described in several organs, and it is not excluded that they could migrate to repair distant tissues. Indeed, they are present in the systemic circulation and they may be activated by pathophysiological stimuli from damaged tissues [16].

Nevertheless, the regenerative activity of SCs is not everlasting, because of senescence processes. This may occur via simple exhaustion of the stem cell pool or arise as a conse-

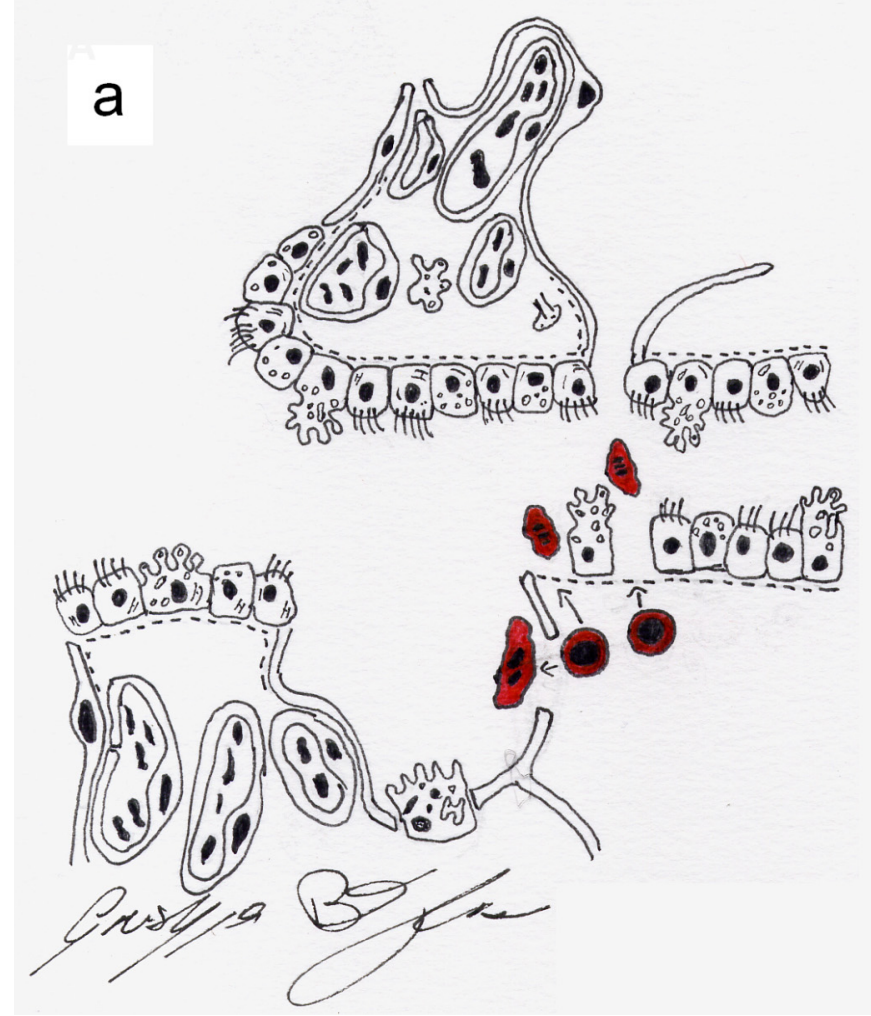

quence of inherited or acquired mutations that impede proper stem cell function. Moreover, cancers may originate from SCs, and also cancers' SCs may self-renew, determining tumour resistance to drugs as well as recurrence of disease [17].

SCs are locally present within niches, and respond to the extracellular matrix and to paracrine factors derived from other cells present in the surrounding tissue, as well as to external environmental influences. Many findings confirm, in vivo, the existence of multipotent adult SCs in many organs, like bone marrow, heart, kidney, brain, and other organs [16]. In each of these organs, these cells may originate one or more cytotypes. Examples include satellite myoblasts in skeletal muscle, and haemangioblasts generating haematopoietic and endothelial cells in bone marrow.

In the lung, the research of SCs progresses slowly due to the complexity of this organ. As conduction airways and alveolar regions have a different embryonic origin, it is a diffused opinion that the study of lung SCs should be split into two parts, namely airway SCs and alveolar SCs [18-21].

With regard to the former, colonies of clonal "transient amplifying" progenitor cells have been isolated from airway tissues [22-24]. In particular, in vivo and in vitro studies suggest that basal cells have the ability to form large differentiated epithelial colonies [25]. As a consequence, it is currently accepted that basal cells of the airway epithelium represent a "stem compartment" in adult mammal lungs. Moreover, Sabatini et al. [26] isolated a pool of fibroblasts from human bronchial mucosa that showed a $<<$ mesenchymal stem cell phenotype $>>$ and a $<<$ multilineage differenti-

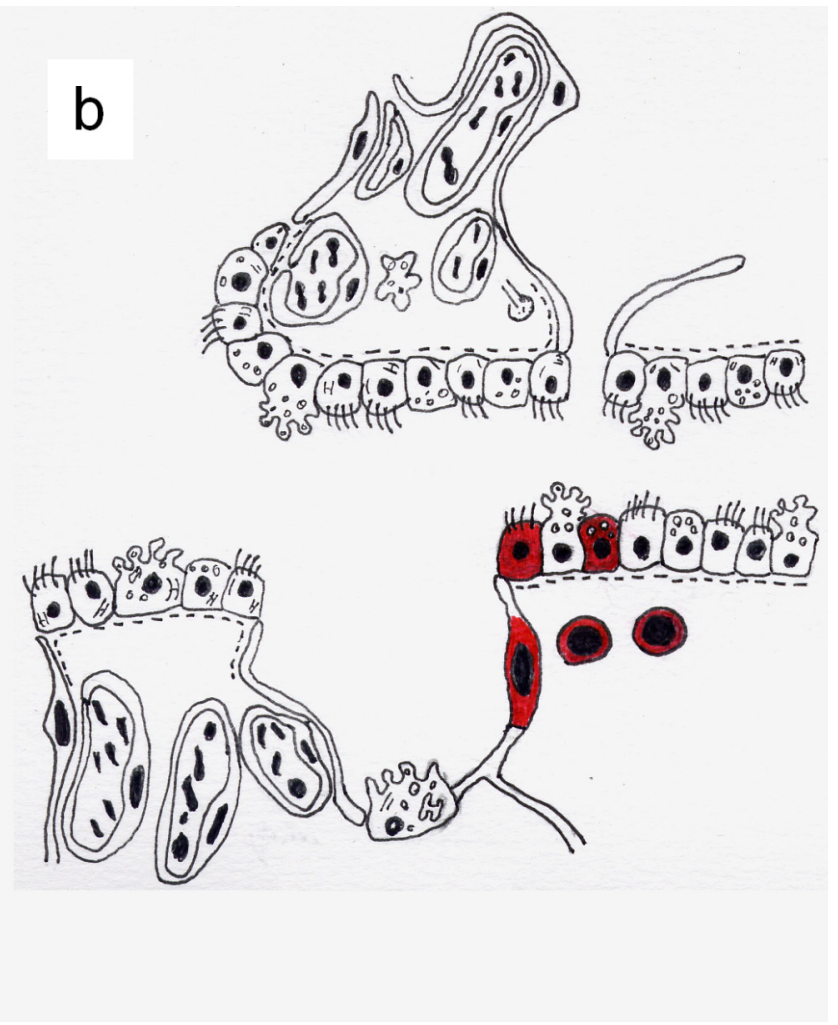

Fig. (2). This draft illustrates the hypothesis that epithelial cells of lobules may have stem precursors contained within the lamina propria. 
ating potentiality $>$. In our opinion, they probably isolated a pool of uncommitted connective progenitors and an exciting challenge could be to transdifferentiate them towards other cytotypes, id est the epithelial one.

With respect to the alveolar SCs, a number of evidences support the hypothesis that TIIPs are the putative SCs of alveolar epithelium. These cells appear to reside at the alveolar-airway junction and express both alveolar (Sp-C) and airway (CC10) epithelial cell markers. For example, an injury damaging only TIPs is commonly repairable, whereas a damage of both TIPs and TIIPs is often fatal [27, 28]. Moreover, some experimental data showed that TIIPs may be stimulated in vitro to proliferate and differentiate into TIPs [29, 30]. In particular, TIIPs differentiated into TIPs, via an intermediate cytotype, in a set of in vitro experiments on foetal lungs [30].

Nevertheless, in our opinion these theories epitomise an old dogma regarding the regenerative capacity of tissues. Indeed, we commonly divide the tissues of the bodies in four families (epithelial, connective, muscular and nervous ones), implicitly excluding the possibility that these tissues share common progenitors also in adult tissues.

What has been emerging recently is that during embryonic development a pool of cells may interrupt this differentiative continuum, to become a reserve of undifferentiated cells. We have proposed to call these cells "embryo stolen adult stem cells" [15]. In particular, these cells should be considered as a pool of undifferentiated cells derived from a bilayered (ecto/endoderm) Embryo, the late blastocyst, that maintain multiple differentiative potentiality also in adult organisms. Should this be true, two populations of embryo stolen adult stem cells may exist in adult organs, the first ecto/mesoderm-committed, and the second endo/mesodermcommitted. These two populations could be responsible for adult tissue homeostasis.

As a consequence, if the maintenance of alveolar homeostasis could be assigned to bronchial-bronchiolar basal cells or TIIP division, the presence of other mechanisms cannot be excluded (Fig. 2), as migration of undifferentiated elements from connective tissue underlying the epithelium.

\section{CONCLUSIONS}

Many issues concerning lung cell biology still remain unsolved. Among which the following questions: how many types of SCs are present in the bronchial mucosa? Which is the SC of the lamina propria? Does it have a common precursor with the epithelial SC? Do TIIPs and Clara's cells preserve a "stem aptitude" also in adults? Do airway basal cells possess unexpected efficient mechanisms for DNA repair? Are fibroblasts of the LP a homogeneous population or a pool of yet uncharacterised multipotent progenitors?

In our opinion, it is imperative to further clarify the lineage relationship between epithelial and connective tissue cells in adult pulmonary tissues, considering the lung not as a "multiple organ" made of bronchi, bronchioles, alveolar spaces, etc. but, for histogenetic reasons, as a unique biological structure. It is the tissue microenvironment in embryo as well as in adult to determine the morphophysiologic features and the morphopathologic states. A substantial effort is necessary to understand the signalling that influence SC pro- liferation and differentiation in order to reach our most significant goal; understanding how to obtain pulmonary regeneration after its destruction.

\section{ACKNOWLEDGEMENTS}

We are grateful to Dr. Giuseppe Battaglia for his drawings.

\section{REFERENCES}

[1] Jeffrey PK. Microscopic structure of the lung. In: Gibson GJ, Geddes JM, Costabel V, Stok PJ, Corrin B (Eds): Respiratory medicine, Elsevier Science, London, 2003; pp. 34-50.

[2] Murray JF. The normal lung. WB Sanders, Philadelphia, 1986.

[3] Sadler TV. Langman's Medical Embryology. Williams \& Wilkins, Baltimore 1995.

[4] Kuhn C. Ultrastructure and cellular function in the distal lung. In: Thurlbeck WM Abell MR. The lung, Williams \& Wilkins, Baltimore, 1978.

[5] Gail DB, Lenfant CJM. Cells of the lung: Biology ad clinical implications. Am Rev Respir Dis 1983; 127: 366-87.

[6] Standring S. Gray's Anatomy. Elsevier Churchill Livingstone, Philadelphia, 2005; Chap. 62: pp. 1057-62.

[7] Colby TV and Youssem SA. Lungs. In: Histology for pathologists, SS Sternberg, Lippincott-Raven Publisher, Philadelphia, 1997; pp. 433-58.

[8] Colby TV, Koss MN, Travis WD. Tumors of the lower respiratory tract. In: Atlas of tumor pathology, Fascicle 13, AFIP, Washington DC, 1995.

[9] Holgate ST, Davies DE, Lackie PM, Wilson SJ, Puddicombe SM, Lordan JL. Epithelial mesenchymal interaction in the pathogenesis of asthma. J Allergy Clin Immunol 2000; 105: 193-204.

[10] Davies DE, Holgate ST. Asthma: The importance of epithelial mesenchymal communication in pathogenesis, inflammation and the airway epithelium in asthma. Int J Biochem Cell Biol 2002; 34 : 1520-6.

[11] Knight DA, Lane CL, Stick SM. Does aberrant activation of the epidermal-mesenchymal trophic unit play a key role in asthma or is it an unimportant sideshow? Curr Opin Pharmacol 2004; 4: 251-6.

[12] Erjefalt JS, Sundler F, Persson CG. Epithelial barrier formation by airway basal cells. Thorax 1997; 52: 213-7.

[13] Chung KF, Barnes PF. Cytokines in asthma. Thorax 1999; 54: 825 57.

[14] Fazzari I. Lo stato delle nostre conoscenze sui tessuti coltivati in vitro in rapporto alle scienze biologiche. Riv Biol 1926; 8: 74-88.

[15] Zummo G, Bucchieri F, Cappello F, et al. Adult stem cells: is the real root into the embryo? Eur J Histochem 2007; 51(S1): 101-3.

[16] Young HE and Black AC: Adult stem cells. Anat Rec A Discov Mol Cell Evol Biol 2004; 276: 75-102.

[17] Asahara T and Kawamoto A: Endothelial progenitor cells for postnatal vasculogenesis. Am J Physiol Cell Physiol 2004; 287: C5729.

[18] Yen CC, Yang SH, Lin CY, Chen CM. Stem cells in the lung parenchyma and prospects for lung injury therapy. Eur J Clin Invest 2006; 36: 310-9.

[19] Engelhardt JF. Stem cell niches in the mouse airway. Am J Respir Cell Mol Biol 2001; 24: 649-52.

[20] Kim CF, Jackson EL, Woolfenden AE, et al. Identification of bronchioalveolar stem cells in normal lung and lung cancer. Cell 2005; 121: 823-35.

[21] Borthwick DW, Shahbazian M, Krantz QT, Dorin JR, Randell SH Evidence for stem-cell niches in the tracheal epithelium. Am J Respir Cell Mol Biol 2001; 24(6): 662-70.

[22] Randell SH, Comment CE, Ramaekers FC, Nettesheim P. Properties of rat tracheal epithelial cells separated based on expression of cell surface alpha-galactosyl end groups. Am J Respir Cell Mol Biol 1991; 4: 544-54.

[23] Schoch KG, Lori A, Burns KA, Eldred T, Olsen JC, Randell SH. A subset of mouse tracheal epithelial basal cells generates large colonies in vitro. Am J Physiol Lung Cell Mol Physiol 2004; 286: L631-42.

[24] Borthwick DW, Shahbazian M, Krantz QT, Dorin JR, Randell SH. Evidence for stem-cell niches in the tracheal epithelium. Am J Respir Cell Mol Biol 2001; 24: 662-70. 
[25] Randell SH. Airway epithelial stem cells and the pathophysiology of chronic obstructive pulmonary disease. Proc Am Thorac Soc 2006; 3: 718-25.

[26] Sabatini F, Petecchia L, Tavian M, Jodon de Villeroché V, Rossi GA, Brouty-Boyé D. Human bronchial fibroblasts exhibit a mesenchymal stem cell phenotype and multilineage differentiating potentialities. Lab Invest 2005; 85: 962-71.

[27] Uhal BD. Cell cycle kinetics in the alveolar epithelium. Am J Physiol 1997; 272(6 Pt 1): L1031-45.
[28] Keeling PL, Pratt IS, Aldridge WN, Smith LL. The enhancement of paraquat toxicity in rats by $85 \%$ oxygen: lethality and cell-specific lung damage. Br J Exp Pathol 1981; 62: 643-54.

[29] Kauffman SL. Cell proliferation in the mammalian lung. Int Rev Exp Pathol 1980; 22: 131-91.

[30] Flecknoe S, Harding R, Maritz G, Hooper SB. Increased lung expansion alters the proportions of type I and type II alveolar epithelial cells in fetal sheep. Am J Physiol Lung Cell Mol Physiol 2000; 278: L1180-5.

Received: November 6, 2008

Revised: March 25, 2009

Accepted: April 8, 2009

(C) Bucchieri et al.; Licensee Bentham Open.

This is an open access article licensed under the terms of the Creative Commons Attribution Non-Commercial License (http://creativecommons.org/licenses/ by-nc/3.0/) which permits unrestricted, non-commercial use, distribution and reproduction in any medium, provided the work is properly cited. 